\title{
(U]
}

Revista Mexicana de Derecho Constitucional

Núm. 40, enero-junio 2019

\section{Common Law and Civil Law: Convergences Beyond a Written Constitution}

\section{Common law y civil law: convergencias más allá de una Constitución escrita}

\section{Estefânia Maria de QUEIROZ BARBOZA* Katya KOZICKI**}

RESUMEN: Este artículo analiza la convergencia entre los sistemas del common law y civil law en relación con los parámetros de la judicial review, particularmente cuando los principios constitucionales, tanto explícitos como implícitos, funcionan para invalidar leyes ordinarias. También el artículo considera la experiencia canadiense para examinar cómo los no escritos pero implícitos principios constitucionales pueden ser usados para el fin de la judicial review. Y de la misma forma se revisa la teoría de The Invisible Constitution, de Laurence Trible. Finalmente, enfrentamos la cuestión de la Constitución viva, la cual incluye el concepto de Constitución como un instrumento vivo más allá de un texto formal.

Palabras clave: common law; civil law; judicial review; principios no escritos; Constitución invisible; Constitución viva.
ABSTRACT: This article analyzes the convergence of the common law and civil law systems in relation to the parameters of judicial review, particularly when constitutional principles, both explicit and implicit, work to invalidate ordinary laws. The article also uses the Canadian experience to examine how unwritten but implicit constitutional principles can be used for the purposes of judicial review. It also reviews the theory of The Invisible Constitution, by Laurence H. Tribe. Finally, we face the question of the living Constitution, which includes the concept of the Constitution as a living instrument beyond its formal text.

Keywords: Common Law; Civil Law; Judicial Review; Unwritten Principles; Invisible Constitution; Living Constitution.

* Adjunct Professor of Law at the Federal University of Paraná and at the Centro Universitário Internacional, undergraduate and graduate programs. $\mathrm{PhD}$ in juridical science - Pontifical Catholic University of Paraná. Vice-President of Italo-Brazilian Association of Professors of Constitutional and Administrative Law (estefaniaqueiroz@uol. com.br).

** Full Professor of Law at the Pontifical Catholic University of Paraná and the Federal University of Paraná. PhD in juridical science - Federal University of Santa Catarina. Research fellow for the National Council for Scientific and Technological Development (CNPq), Brazil (kkozicki@uol.com.br). 
SUMMARY: I. Introduction. II. Unwritten Constitutional Principles. III. Invisible Constitution. IV. Constitutional Approaches. V. Living Constitution. VI. Final Remarks. VII. Bibliographic.

\section{INTRODUCTION}

In recent decades, constitutional and international systems have experienced a number of transformations, particularly due to the protection afforded to fundamental rights by national Constitutions or afforded to human rights by international treaties or conventions incorporated in several countries.

These changes started in the mid-20th century with a change in the legalist view of the Rule of Law and the adoption of Democratic Constitutions - with an extensive catalog of fundamental rights and guaranteesconsidered supreme and as limitative of the Parliament. Similarly, note the preponderance of Human rights. Such rights also started to operate as limits to the Parliaments and, therefore, as a material parameter for judicial review even in countries that lack any written Constitution, such as England, for example, since the Human Rights Act of 1998 and the Constitutional Act of 2005, and New Zealand, since the New Zealand Bill of Rights Act of 1990.

Both in countries with written constitutions and in countries without written constitutions, human or fundamental rights have been functioning as parameters for judicial review. The fundamental materiality of these rights, which impose restrictions on Parliaments, does not depend upon their formal establishment in a Constitution, treaty or International Convention on Human Rights, or, furthermore, in a formal law, as is true in New Zealand.

Hence, there is a common morality in civil law and common law systems based on the principle of human dignity; thus, other, unwritten principles or rights could be accepted as long as they derive from the concept of human dignity.

Nonetheless, as will be further demonstrated in this article, beyond the implicit rights resulting from human dignity or other rights and principles expressed in the Constitution, other rights can be derived via an inverse process of interpretation. In other words, if it is possible to say that the right to equality originates from one of the dimensions of dignity, according to which "the success and the failure of any human life is important in itself", 
it is also possible to interpret in an inductive manner that a norm that forbids racial discrimination exists because the principle of equality provides a basis for that norm.

The question that arises is the following: If written norms are in fact attempts to posit principles and rights constructed historically by society, is there a chance that texts cannot foresee all of these rights? Thus, the doctrine and jurisprudence of the common law countries have developed concepts such as unwritten principles, invisible constitution and living Constitution to comprehend these phenomena.

For such purposes, common law and civil law systems converge in relation to the material parameter for judicial review, particularly when unwritten constitutional principles inside or outside the constitutional text and implicit constitutional principles function as parameters to invalidate ordinary laws.

This theme is precisely that which this article is going to explore, seeking to show that the material parameters for judicial review are beyond those written in normative texts. In other words, human and fundamental rights have a moral foundation that is an element of convergence between civil law and common law systems. First, how unwritten principles of a formal constitutional text can be used as parameters for judicial review will be analyzed by focusing on the Canadian experience in particular.

Second, the work The Invisible Constitution ${ }^{1}$ by Laurence H. Tribe, in which the author defends the existence of an invisible Constitution alongside the visible Constitution of the United States, will be studied.

The issue of the living Constitution, which envisions the Constitution as a living instrument that goes beyond the formal text, showing that the Constitution is a dynamic instrument, the interpretation of which will change over time, will also be addressed. It will be necessary, then, to address the issues of constitutional mutation and how judicial interpretations of the Constitution reflect and provide new content to the Constitution.

\section{UNWRITTEN CONSTITUTIONAL PRINCIPLES}

As a starting point, the unwritten constitutional principles will be the focus of this analysis to show that they are a result of interpretative work by

1 Tribe, Laurence H., The Invisible Constitution, New York, Oxford University Press, 2008. 
constitutional jurisdictions that must identify them and give them signification. When the Judicial Branch, but not the Legislative, is faced with the possibility of defining the unwritten principles, be they implicit or outside the text, there follows a consequent expansion of the role and importance of that Branch.

It is important to emphasize that the presence of implicit principles, and of implicit assumptions, is inherent not only in juridical legal and constitutional texts but also to texts that involve language in general. If a Constitution, just as other written laws, is an attempt to communicate juridical norms, its meaning is therefore influenced by principles of linguistic communication, which include the principle that states that in every communication, its content is never fully expressed in the words used to express it. $^{2}$ The meanings derived from interpretations depend upon previously established information that must be viewed as truthful. In other words, any statement involving language also involves the assumption of implicit and pre-established values. ${ }^{3}$

Therefore, one cannot establish in writing exactly and literally what one means to say. Thus, even when several possible meanings are established to avoid a wrongful interpretation, many other possible meanings will exist that were not considered or evaluated.

Thus, the understanding of any written text, constitutional or legal, also depends upon implicit assumptions, including what the Courts view as common sense. It is also necessary to include preexisting juridical principles.

It is important to realize that normative texts, particularly abstract constitutional provisions, often offer ambiguous instructions, allowing for new interpretations and alterations of long-standing precedents. In fact, if a

2 Goldsworthy, Jeffrey, "Unwritten Constitutional Principles", Expounding the Constitution. Essays in Constitutional Theory, New York, Cambridge University Press, 2008, p. 279.

3 Liber, in the 19th century, provided the following example: "Suppose a housewife says to her household employee, «Bring me some meat for the soup», giving the employee an amount of money at the time. The employee will not be able to execute the order without interpretation, even if it seems easy and involves a quick procedure. Common sense and good will tell the household employee that the housewife meant the following: 1 . That she should immediately leave, or leave as soon as she finishes her tasks; 2. That the money she received is to pay for the meat, and it is not a gift to the worker; 3 . That she should buy pieces of meat commonly used in the house to prepare soups; 4 . That she should buy the best piece that she can afford...". Where would be the end? Lieber, F., Legal and Political Hermeneutics (1839), pp. 28-39. See in Goldsworthy, Jeffrey, op. cit., p. 297. 
Constitution, just as other written norms, is an attempt to publicize juridical norms, as Goldsworthy explains, its meaning is presumably affected by general linguistic communication principles. One such principle establishes that the content of a communication is rarely fully expressed by the words used to convey it. ${ }^{4}$

In countries adopting a common law model, there is an assumption, for instance, that the laws enacted by the Parliament should not exceed the authority of those who drafted them, that they are not retroactive and that they do not offend the fundamental principles of common law. ${ }^{5}$ Notice that in Brazil, general principles of law that are not expressed in any of the normative documents are often used.

In the United States court case Reegs v. Palmer ${ }^{6}$ in which the court addressed the matter of whether an heir who killed a testator could receive his inheritance, the decision was based on a general and implicit principle of law, which states that wrongdoers should not profit from their wrongs. A similar case occurred in England, when a pension was not granted to a widow who murdered her husband. ${ }^{7}$

The issue concerning unwritten constitutional principles is not exclusively inherent in common law tradition or in countries that do not have a written constitutional text, such as England and New Zealand, but it is also common in countries with a written Constitution, such as the United States and Brazil. ${ }^{8}$

4 "For example, when I order a hamburger, I do not bother to specify that it should not be poisonous or inedible. The possibility of being served such a hamburger would probably not even occur to me. Yet if I were served with one, I could plausibly claim that my order implicitly excluded it - that it was inconsistent with what I obviously meant when I placed my order". Ibidem, p. 279.

5 Ibidem, p. 300.

6 Dworkin provides a detailed analysis of the case in Levando os direitos a sério, São Paulo, Martins Fontes, 2002, pp. 37 et seq.

7 R.v Chief National Insurance Commissioner. Cf. Goldsworthy, Jeffrey, op. cit., p. 301 .

"All of the constitutions I am familiar with have given rise to claims that they include or presuppose «unwritten» or «implied» principles. These principles can be relatively specific, such as the implied freedom of political communication, first «discovered» by the High Court of Australia in 1992. Or they can be quite abstract, such as «the rule of law», which is viewed almost everywhere as a constitutional principle of some type. They might concern individual rights or freedoms, governmental powers or immunities, or institutional safeguards such as the separation of judicial power. But all, in some way, qualify or override the authority of legislatures". Ibidem, p. 277. 
It is usual for written Constitutions to have implicit and abstract principles, expressed in a general manner and in open language in such a way that they are capable of flexible application to changeable circumstances in accordance with changes in society.

The importance of studying this subject is justified because, even when unwritten, implicit constitutional principles can invalidate ordinary legislation, serving as parameters for constitutional control. The question raised is that both the specification of what these principles are and of what their contents are result from the Judicial Branch's interpretation, which can lead to a great abuse of discretion by this branch and, at the same time, to juridical insecurity and instability for citizens.

Some issues concerning unwritten constitutional principles consist of their own definition and of to whom would be given the authority to unveil them, because the constituent power itself did not explicitly establish or define these principles in the Constitution.

Conversely, it is also important to highlight that the material Constitution goes beyond the formal Constitution and, similarly, so do the unwritten constitutional principles, which brings us to seek the validity and supremacy of these norms beyond their formal origins. By way of explanation, beyond the words expressed in the text, there is a reflection upon their meaning, which is supported by the political, moral, and juridical culture. That is, when speaking of unwritten constitutional principles, one is referring to unwritten norms that are essential to the history of a nation, to its identity, its values, and its juridical system.

Upon examining the origin of Canada's written Constitution, Mark D. Walters explains that it emerged in a context that forged the common law thinking, in which unwritten fundamental law is considered an assertion of the supremacy of natural law, right reason or universal principles of political morality and human rights over legislation that had informed common law thinking. ${ }^{9}$

Moreover, notice that even in a "common law constitution", the Judicial Branch plays the role of a mediator between the citizens and the State. The power of the courts to demand the fulfillment of the rule of law derives not from any established written Constitution but from general principles that

9 Walters, Mark D., "The Common Law Constitution in Canada: Return of Lex no Scripta as Fundamental Law", The University of Toronto Law Journal, vol. 51, no. 2, spring, 2001, p. 136. 
establish when citizens' acceptance that the State's demands are truthful, whether due to an actual recognition of its legitimate demands or due to the virtue of its intrinsic reason as manifestations of a genuine common good.

Thus, according to Trevor Allan, although for practical reasons the courts must, in the final analysis, establish the legitimacy of the use of the State's power, in any particular case, this establishing represents, or should represent, the decision a conscious citizen would arrive at on his own concerning the matter in question. ${ }^{10}$

Although modern constitutions' bills of rights reinforce the idea of coercion or of coercive demand to fulfill the law, these bills of rights do not establish the content of the right, which evidences that principles are previous and independent from any formula through which they are expressed. In other words, written constitutions of liberal democracy do nothing more than summarize the progressive development of common law. That is, the Constitution and constitutional principles have a material content, and their written provision is but a formal representation of values already present and accepted in a given society. Consequently, it is possible to defend the convergence of written constitutions in countries with a tradition in civil law or common law because in both systems, interactions between the Legislative and Judicial Branches are consequently much more a matter of establishing the demands of the constitutional law, strengthening what is intrinsic, than they are a matter of following the specific prescriptions of a constitutional text. ${ }^{11}$

Beyond the above, this article defends that the Constitution is not a text. The text is only an attempt to represent the Constitution. Thus, the fact that England has no written Constitution is not an obstacle to the defense of the convergence of the systems because England has a material Constitution. Furthermore, the recent edition of the Human Rights Act that internalized the European Summit on Human Rights in that country can be considered a written constitutional text. Regardless, the interpretative role to be executed by the constitutional judges when facing difficult cases that involve human rights is the same and does not depend upon its formal origin.

10 Allan, T. R. S., "In Defence of the Common Law Constitution: Unwritten Rights as Fundamental Law”, LSE Legal Studies Working Paper 5, January 22, 2009, available at: http://ssrn.com/abstract $=1331375$ or http://dx.doi.org/10.2139/ssrn.1331375 (acessed on: August 17, 2018).

11 Goldsworthy, Jeffrey, op. cit., p. 289. 
Upon analyzing a few decisions by the Supreme Canadian Court, Mark D. Walters concluded that the written Constitution is accepted in Canada because there is an unwritten common law Constitution. ${ }^{12}$ The Court states that the legal authority of the written Canadian Constitution derives from these unwritten constitutional principles. Laurence $\mathrm{H}$. Tribe also shares this idea ${ }^{13}$ when the author accentuates that it is through the invisible Constitution that the visible Constitution is accepted.

Likewise, when Jeffrey Goldsworthy defines "strong common law constitutionalism"14 as a system in which common law is the last source of laws' and possibly of the constitution's authority, he explains that the unwritten British Constitution is composed of common law principles that are the source of all government authority, including the authority of the Parliament to elaborate laws. Common law would be, in this manner, previous to the legislative supremacy, which is defined and regulated by it. It is usual to find this statement expressed in written constitutions or constitutional documents because they also originate from common law. For example, it is argued that if the British Parliament eventually enacts a written Constitution, its authority relies on the Parliament and, consequently, originates indirectly from the same common law unwritten Constitution. ${ }^{15}$

The Canadian Supreme Court has established that the Canadian Constitution is first and foremost written but that, behind the written words, there are vital, unstated premises upon which the text is based. Therefore, a number of unwritten constitutional principles exist to which judges can give normative power. ${ }^{16}$

The emergence of a Lex non scripta theory as a fundamental law in the Canadian legal system can be noticed in the Supreme Court rulings in

12 Walters, Mark D., "The Common Law...", op. cit., p. 92.

13 Tribe, Laurence H., op. cit., p. 9.

14 Goldsworthy, Jeffrey, op. cit., p. 290. According to the conception of Dworkin, the Parliament's authority originates and is limited by “...abstract principles of political morality, the identity and content of which are ultimately for the judges to authoritatively determine".

15 Ibidem, pp. 289 and 290. "Allan maintains that all the constitutions in former Commonwealth countries are ultimately based on unwritten principles of constitutionalism and the rule of law, which lie at the heart of the common law tradition".

16 Concerning the case of Quebec's Secession, see note 19, above. Walters, Mark D., "Written Constitutions and Unwritten Constitutionalism", en Huscroft, Grant (ed.), Expounding the Constitution: Essays in Constitutional Theory, New York, Cambridge University Press, 2008, pp. 246 and 247. 


\section{the cases New Brunswick Broadcasting, ${ }^{17}$ Provincial Judges ${ }^{18}$ and Quebec} Secession Reference, ${ }^{19}$ in which the Court refers to unwritten rights, rules, powers, norms and principles, and implicit principles and common law.

17 New Brunswick Broadcasting Co. v. Nova Scotia (Speaker of the House of Assembly), (1993) 1 S.C.R. 319. In this case, the Supreme Court of Canada understood that parliamentary privilege is an unwritten norm, implied by the preamble to the Constitution. Available at: https://scc-csc.lexum.com/scc-csc/scc-csc/en/item/957/index.do (accessed on: september 11, 2016).

18 In the present case, the Supreme Court of Canada understood that the principle of independence of provincial court judges is an unwritten norm, implied by the preamble to the Constitution. "Toutefois, je tiens à ajouter une mise en garde. Comme je l'ai dit dans l'arrêt New Brunswick Broadcasting, précité, à la p. 355, 1'histoire constitutionnelle du Canada peut être considérée, en partie, comme une évolution «qui a abouti à la suprématie d'une constitution écrite définitive». La préférence pour une Constitution écrite repose sur bon nombre de raisons importantes, particulièrement la certitude du droit et, par ce moyen, la légitimité du contrôle judiciaire fondé sur la Constitution. Compte tenu de ces préoccupations, qui sont au cœur de l'idée de constitutionnalisme, il est de la plus haute importance de préciser la source de ces normes non écrites. À mon avis, il est possible d'expliquer l'existence de bon nombre des règles non écrites de la Constitution canadienne en se reportant au préambule de la Loi constitutionnelle de 1867...". Reference Remuneration of Judges of the Provincial Court (P.E.I.), (1997) 3 S.C.R. 3, available at: http://scc-csc.lexum.com/scc-csc/scc-csc/fr/item/1541/index.do (accessed on: septembre 7, 2016).

19 Reference re Secession of Quebec, (1998) 2 S.C.R. 217, available at: http://scc. lexum.umontreal.ca/en/1998/1998scr2-217/1998scr2-217.html (accessed on: september 10, 2016). "What are those underlying principles? Our Constitution is primarily a written one, the product of 131 years of evolution. Behind the written word is an historical lineage stretching back through the ages, which aids in the consideration of the underlying constitutional principles. These principles inform and sustain the constitutional text; they are the vital unstated assumptions upon which the text is based. The following discussion addresses the four foundational constitutional principles that are most germane for resolution of this Reference: federalism, democracy, constitutionalism and the rule of law, and respect for minority rights. These defining principles function in symbiosis. No single principle can be defined in isolation from the others; nor does any one principle trump or exclude the operation of any other... Underlying constitutional principles might in certain circumstances give rise to substantive legal obligations..., which constitute substantive limitations upon government action. These principles can give rise to very abstract and general obligations, or they can be more specific and precise in nature. The principles are not merely descriptive, but are also invested with a powerful normative force, and are binding upon both courts and governments. «In other words», as this Court confirmed in the Manitoba Language Rights Reference..., «in the process of Constitutional adjudication, the Court may have regard to unwritten postulates which form the very foundation of the Constitution of Canada». We now turn to a discussion of those underlying constitutional principles. This reasoning was used to justify the federalist principle, which is not within 
What one perceives from the decisions above is that, before the written Constitution, an unwritten Constitution exists that has evolved historically. The written Constitution supposedly came to set a parameter of certainty for judicial review, but its adoption does not mean excluding the unwritten Constitution from the Canadian common law. The unwritten Constitution itself and its unwritten principles serve as the basis for the written Constitution. ${ }^{20}$

The idea of an unwritten Constitution is not, thus, a product of an illegitimate or revolutionary judicial activism, ${ }^{21}$ explains Walters. Nor is the Constitution of the Canadian common law restricted to a previous set of laws and rules of the British common law. The Reference re Secession of Quebec case, for example, emphasized that the Canadian unwritten Constitutional law derived from customary sources that are unique in the Canadian Constitutional history.

Although some of these sources appear to be independent and prior to the written Canadian Constitution, others emerge from a contextual reading of the Constitutional text itself and, in particular, from the political compromise that led to the writing of Constitutional provisions. Thus, the Court identified two types of unwritten Constitutional norms: those independent (freestanding), whose source is located outside the Constitution, and those that emerge from the written text of the Constitution (text-emergent). ${ }^{22}$

The novelty is not in Constitutional lex non scripta itself but in questions concerning its supremacy and justiciability. Walters explains that when the Supreme Court applies British Constitutional principles as bin-

the written constitution, but is part of Canada's history. Therefore, albeit implicit, it is considered fundamental to the Canadian constitutional system. Finally, the ruling stated the impossibility of secession of the State of Quebec and that, in this manner, even in the event of a larger manifestation by the population, an eventual secession could only occur if there were an amendment to the Constitution.

20 In the opposite sense, Leclair believes that unwritten principles bring uncertainties. He notes that in the Secession case, the rules adopted by the Court are common law rules, not properly the case of new rules creation. However, when you have a precedent giving the judiciary the possibility to give legislative effect to a Constitutional unwritten principle, allowing it to reset Canada's Constitutional past and future, one might create a certain insecurity and unpredictability of the law. Leclair, Jean, "Canada's Unfathomable Unwritten Constitutional Principles", Queen's Law Journal, no. 27, 2001-2002, pp. 406 and 407.

21 Walters, Mark D., "The Common Law...", op. cit., p. 94.

22 Leclair, Jean, op. cit., pp. 398 and 399; Walters, Mark D., "The Common Law...", op. cit., p. 98. 
ding norms in Canada today, it is not invoking the English Law in the original meaning that this expression had in subsection 2 of the Westminster Statute ${ }^{23}$ but is invoking unwritten legal norms similar to those recognized by the Constitution of the English common law. ${ }^{24}$

Conversely, there is an acceptance both in the United States and in Canada that behind the written Constitution, there are rights protected by an unwritten Constitution. Therefore, the original constituent power of the people is not unlimited because it should begin from an unwritten Constitution or common law system; that is, unwritten Constitutions must be understood from the perspective of a theory of an unwritten Constitutionalism. ${ }^{25}$

Note that this idea is also present in countries with a tradition in civil law that adopted Constitutionalism, to the extent that the original constituent power neither emerges in a "historical and cultural vacuum" nor finds limits. In other words, according to Canotilho, the constituent power must obey "spiritual, cultural, ethical and social standards and models of conduct rooted in the general legal conscience of the community", which is exactly the idea of unwritten constitutionalism. Similarly, principles of justice must be observed, regardless of their configuration as suprapositive or supralegal principles. Finally, there are principles of international law that must also be observed by the constituent power, such as the "separation of powers, the self-determination principle and the principle of observance of human rights". ${ }^{26}$

In this dimension, the idea that the common law Constitution provides grounds for the validity of the written Constitution is the same as an invisible Constitution or the same thought that the Constitution is a set of norms that is based on abstract principles of political morality that support and limit the activities of the Parliament. The Judiciary, as the final authority, is the one to state, explain and demand compliance to those principles.

The criticism of unwritten constitutionalism is primarily advanced in countries that adopt a written Constitution, for two reasons in particular. First, because accepting the judicial imposition of unwritten restrictions on legislative authority represents some type of resurrection of natural

23 Statute of Westminster (1931), available at: http://www.statutelaw.gov.uk/.

24 Leclair, Jean, op. cit., pp. 391 and 392; Walters, Mark D., "The Common Law...", op. cit., pp. 139 and 140 .

25 Walters, Mark D., "Written Constitutions and...", op. cit., p. 247.

26 Gomes Canotilho, José Joaquim Direito constitucional e teoria da Constituição, 3a. ed., Coimbra, Almedina, 2000, p. 77. 
law or historically constructed law, doing so would typify morality statements by the judges about the decisions made by the elected Legislative representatives. The unwritten Constitution would come out, therefore, as a "cloudland" in which judges could enter and leave with their own theories of Constitutional limitations. A second criticism concerning unwritten Constitutionalism is that many of its examples would be of cases of structural analysis, a Constitutional interpretation mode in which one reaches logical deductions from the structures established in the written Constitution itself. In this hypothesis, unwritten constitutionalism would not actually be "unwritten" but rather an approach consisting of systematic interpretation and text logic. ${ }^{27}$ In Brazil, one speaks of this approach in relation to implicit principles and rights that arise from the system itself.

Although the written Constitution is viewed as the law representing the sovereign will (law-as-sovereign will), the unwritten Constitution works as the logic of law because of reason (law-as-reason). ${ }^{28}$

Walters explains that in the common law system, there is a concept of unwritten law that can be summarized as follows. On the one hand, written law would be a metaphor representing the sort of legal proposition that is set by a lawmaker using a linguistic formula that is to be employed specifically by judges, exhausting the law for the matters to which it is held to apply. To interpret and apply written law, then, requires determining how the general or specific language of a rule applies to specific situations.

On the other hand, unwritten law would be a metaphor that represents the sort of legal proposition that is derived through a discourse of reason in which specific legal propositions directly or indirectly relevant to the matter under consideration are examined. These propositions are examined not as fundamental expressions of rules that exhaust the law at issue but as manifestations of more-abstract principles of secondary reason from which, after an interpretative oscillation between the specific propositions and the general principles they presuppose and due consideration of the aspiration of equality of reason, other specific legal propositions can be derived. Thus, unwritten law is not simply historical custom or natural reason. It is actually a discourse of reason that seeks a unity of reason through an inductive ascent from particular manifestations of general principles to the general principles themselves, and then a descent back again to the level of

\footnotetext{
27 Walters, Mark D., "Written Constitutions and...”, op. cit., p. 247.

28 Idem.
} 
specifics to articulate new rules or rights which cohere, in principle, with established rules and rights. ${ }^{29}$

The author points to the existence of convergence between written and unwritten law according to the common law view of law. Written law only relatively exhausts the law on a point. In fact, the meaning of general and abstract expressions of written law in individual cases is shaped by judicial commitment to equality, or a broad sense of fairness guaranteed by the unwritten law of reason..$^{30}$ However, it is clear that a rule of law established through the canonical expression of a lawmaker might later be considered by judges a mere reflection of more-abstract legal principles from which other rules cohering in principle with the legislated rule might later be identified. By means of judicial exposition, written law can become unwritten law. ${ }^{31}$

One can also apply the inductive method that is applied to the texts enunciated in judicial decisions to achieve general principles underlying written norms, verifying that these principles are written expressions of unwritten principles.

One cannot forget that the expressions "written law" and "unwritten law" do not refer to the existence or absence of constitutional documents but to metaphors that symbolize distinctive approaches to constitutional interpretation. ${ }^{32}$

Thus, Venn Dicey contrasted England's unwritten constitutional law with written Constitutions of other countries:

There is in the English Constitution an absence of those declarations or definitions of rights so dear to foreign Constitutionalists... The difference... between the Constitution of Belgium and the English Constitution may be described by the statement that in Belgium, individual rights are deductions drawn from the principles of the (written) Constitution, whilst in England the so-called principles of the Constitution are inductions or generalizations based upon particular decisions pronounced by the Courts as to the rights of the given individuals. ${ }^{33}$

29 Ibidem, pp. 253 and 254.

30 Ibidem, p. 254.

31 Idem.

32 Idem.

33 Venn Dicey, Albert, An Introduction to the Study of the Law of the Constitution, 8a. ed., s.1., s.n., 1908 apud Walters, Mark D., "Written Constitutions and...", op. cit., pp. 254 and 255. 
Thus, Walters acknowledges that the main difference between written and unwritten law is not so much the presence or absence of a written constitutional document but the difference between a system in which judges give special meaning to general and abstract propositions of constitutional law that are expressed in formal and solemn form and a system in which judges articulate constitutional law by inferring general principles from a non-formal and non-solemn set of specific legal propositions. This distinction is similar to that implied by the written and unwritten law metaphor. ${ }^{34}$

It can be argued that this difference is becoming smaller. That is, in common law systems, the adoption of written constitutional documents leads to change in the interpretive work of judges, which is not only no longer inductive, inferring general principles from previous decisions to be applied in new cases, but also deductive, because the new Constitutions expressly provide general and abstract propositions — such as fundamental rightswhich must grant meaning in their application to a case.

The reverse is also true. The adoption of constitutionalism and the codification of human rights in the Constitutions of civil law countries have introduced a new way of thinking about the law, whether it is searching for the content of fundamental rights written in an unwritten Constitution or seeking a new interpretation of judicial decisions, seeking in them a set of propositions and meanings that are not solemnly expressed.

It is also necessary to present the differences between the formal and the material dimensions of reason in the theory of unwritten law in the common law system.

One can comprehend that when judges in common law jurisdictions - committed to liberal democratic values - interpret fundamental human rights, they engage in an interpretative activity that is, despite superficial differences, essentially the same as that which occurs within common-law jurisdictions that have not adopted written constitutional guarantees. To interpret and apply the fundamental right to equality, for example, it is necessary to expound values that constitute an unwritten rule of reason that defines the core of the idea of valid law within liberal democratic societies, including those without written Constitutions. ${ }^{35}$

Hence, one can state that the true meaning of a constitutional text relating to human or fundamental rights reflects the understanding of the requirements of the rule of law, articulated in specific cases by analysis and

\footnotetext{
34 Idem.

35 Ibidem, p. 269.
} 
development of the common law. Thus, far from making the unwritten rule of reason redundant, the adoption of written human or fundamental rights protections in writing at best alters how common law values pertaining to the rule of law are interpreted. ${ }^{36}$

Thus, one must question to what extent and degree the existence of a written Constitution actually changes the character of legal analysis at the most fundamental level. Written constitutional law, at least in relation to the values intrinsic to the liberal conception of the rule of law, blends into unwritten constitutional law through judicial interpretation that seeks a coherent and justified vision of constitutional order. Formal distinctions between written and unwritten law are actually blended by the substantive connections between them by means of human rights. ${ }^{37}$

In other words, in a common-law jurisdiction without a written constitutional provision that guarantees equality, judges must for example infer a general principle of equality through a discourse of reason that treats legal propositions as manifestations of more general and abstract principles rather than as formal statements of the law before they can apply that general principle of equality to specific cases. In a common-law or civil-law jurisdiction having a written Constitutional guarantee of equality, judges are saved the trouble of the first step in the interpretative process, the general principle having been given to them in a formal form by the text, thus allowing them to proceed directly to the task of applying it to specific cases. ${ }^{38}$

Mark D. Walters concludes that in common law jurisdictions with or without a written Constitution that fails to cover matters in an exhaustive manner, formal unwritten constitutionalism is inevitable. In fact, no common law or civil law jurisdiction has managed to codify in written form all of constitutional law. ${ }^{39}$ Nevertheless, some written Constitutions appear to protect the fundamental rights of equality and due process that are intrinsic to a liberal conception of the rule of law. ${ }^{40}$

\footnotetext{
36 Idem.

37 Ibidem, p. 270.

38 Ibidem, pp. 270 and 271.

39 This point is also true in civil law jurisdictions that have a written Constitution, because it is in the constitutional text's nature to leave a fluidity between the constitutional text and the constitutional reality. Moreover, a constitutional text cannot be exhaustive with respect to human and fundamental rights in particular because these rights are built daily in the fields of social struggles.

40 Walters, Mark D., "Written Constitutions and...", op. cit., pp. 272 and 273.
} 
In fact, even the fundamental rights set forth in a written document will demand, at the moment of its interpretation and application, elements present in the set of principles that form the political morality of a community through the study of their judicial decisions, their Constitutional practice and their history.

\section{INVISIBLE CONSTITUTION}

Another work worth mentioning with respect to the theme under analysis is The Invisible Constitution, by Laurence H. Tribe. The author is careful to emphasize that the invisible Constitution differs in two important aspects from the unwritten Constitution literature that William Bennett Munro $^{41}$ inaugurated in the 1930s. The first is that the author is not concerned with justifying a high-profile role for judges, including the Supreme Court, but with exploring the substance of the Constitution regardless of who is attempting to understand and apply it. The second aspect mentioned by Tribe is that his focus is not on what is invisible around the Constitution but on what is invisible within it. In other words, his book is about what is in the US Constitution but cannot be seen when one reads only its text. ${ }^{42}$

The author states that some of the US Supreme Court landmark rulings, such as Brown v. Board of Education and Marbury v. Madison, due to their social acceptance and the enforcement of judges, eventually won Constitutional status, to the point they were understood and applied but not revisited or revised. "In other words, it was treated as though it were part of the Constitution itself". ${ }^{43}$ Thus, he accepts that judicial decisions that create precedents and that have great public repercussion are part of the Constitution itself.

These cases are handled by Tribe as "superprecedents" that would be unthinkable for any subsequent Court to overrule. He explains that only the cases Brown v. Board of Education and Marbury ${ }^{44}$ v. Madison achie-

41 Munro, William Bennett, The Makers of the Unwritten Constitution: The Fred Morgan Kirby Lectures, s.l., Delivered at Lafayette College, 1929.

42 Tribe, Laurence H., op. cit., pp. 11-13.

43 Ibidem, p. 19.

44 In this case, it was alleged that segregation between black and white children in public schools, based on race, denied black children equal protection before the law guaranteed by the 14th Amendment. Based on the understanding that "We conclude that, in the field of public education, the doctrine of «separate but equal» has no place. Separate 
ved this constitutional status. He concludes that this phenomenon attests to the power of the written word in the American constitutional order: "if the Constitution is a nearly sacred text, there is an unbridgeable gap between the one set of words that constitutes it and the mere collections of words of those who interpret and apply it". ${ }^{45}$

Thus, the author states that many of the Supreme Court precedents construing various parts of the written Constitution come to occupy a privileged place in American law, acquiring the status of constitutional law by virtue of their assimilation into the broader popular culture and by the accommodation to those decisions by the organizations and institutions that initially resisted them. ${ }^{46}$

Many other precedents that are controversial and currently considered unconstitutional serve to state what the Constitution and constitutional law should not be, including decisions such as Dred Scott v. Sanford, ${ }^{47}$ Plessy v.

educational facilities are inherently unequal. Therefore, we hold that the plaintiffs and others similarly situated for whom the actions have been brought are, by reason of the segregation complained of, deprived of the equal protection of the law guaranteed by the Fourteenth Amendment. This disposition makes unnecessary any discussion whether such segregation also violates the Due Process Clause of the Fourteenth Amendment", the Supreme Court ruled unconstitutional the state laws that established this segregation. Brown v. Board Of Education, 347 U. S. 483 (1954), available at: http://caselaw. lp.findlaw.com/scripts/getcase.pl? court $=u s \& v o l=347 \&$ invol $=483$ (accessed on: August 10, 2010).

\section{Idem. \\ 46 Idem.}

47 In Bruce Ackerman's view, "From a moral point of view, Dred Scott is the single darkest stain upon the Court's checkered history" (Ackerman, Bruce, We the People: Foundations, Massachusetts, The Belknap Press of Harvard University Press, 1991, p. 63). About this case: "In the present case, the Supreme Court declared unconstitutional «The Misouri Compromise» that limited slavery north of the Mason-Dixon line, based on a precedent which established that, when returning to a slave state, the slave, even if he had been found free in another State, should be controlled by the law of that State, and therefore Dred Scott had no right to remain free when he returned to Missouri, a State where slavery was permitted. However, rather than just deciding the case at issue, the Supreme Court ruled that African descendants, even when they were made citizens of the State, according to the legislation of a State of the Federation, could never become citizens of the United States and therefore could not sue in federal court. The decision had a rather negative repercussion and, according to Bickel, it was the trigger for the American civil war, as Lincoln made this decision a pretext to justify the war. One can even argue that the absence of protection to the black minority has generated broad political and social instability, leading to the precipitation of the US Civil War" (Queiroz Barboza, Estefânia Maria de, Constitutional Jurisdiction: between Constitutionalism and 
Ferguson, ${ }^{48}$ Lochner v. New York ${ }^{49}$ and Korematsu v. United States. ${ }^{50}$ Such decisions eventually became paradigmatic examples of how a Constitution should never again be read, thus providing crucial sources for understanding the Constitution. These lessons are to be found not within the Constitution's visible language but outside it. According to Tribe, anything that is not written in the Constitution must have a more shadowy, dubious, and less legitimate status than that enjoyed by its words. ${ }^{51}$

The author wants to make clear that when one accepts the existence of unwritten principles such as anti-secession or judicial review, it is not because they are facets of some body of divine, natural or higher law. In fact, nearly all scholars who have written concerning what they call the "unwritten Constitution" have stated that this body of natural laws must be considered real, legally binding and entitled to prevail over mere statutes or executive orders. Tribe does not believe in an imaginary natural law behind or prior to the Constitution but in rights historically constructed ${ }^{52}$ that ultimately justify and give validity to the written Constitution itself. Thus, the focus of such debate has been confined to the legitimacy of having unelected judges resort to an unwritten norm when invalidating laws passed by the people..$^{53}$

Democracy, Belo Horizonte, Forum, 2007). See also Bickel, Alexander M., The Least Dangerous Branch: The Supreme Court at the Bar of Politics, 2a. ed., New Haven, Yale University Press, 1986, pp. 69 and 70.

48 Plessyv. Ferguson, 163 U.S. 537, 16 S. Ct. 1138, 41 L. Ed. 256. Available at: https:// www.law.cornell.edu/supremecourt/text/163/537\#writing-USSC_CR_0163_0537_ZS (accessed on: September 10, 2016).

49 In the present case, the Supreme Court ruled unconstitutional a law of the State of New York that limited the working hours of bakery employees to sixty hours per week and ten hours a day, understanding that it violated the liberty of contract protected by the Due Process Clause of the 14th Amendment, Lochner v. People of State of New York, 198 US 45 (1905), available at: http://caselaw.lp.findlaw.com/cgi-bin/getcase.pl? court $=$ us\&vol=198\&invol=45 (accessed on: December 29, 2009).

50 Decision in which the Supreme Court of the United States declared constitutional an order that determined that the descendants of Japanese who were living in military areas should be sent to internment camps during World War II, for safety reasons, which would justify the curtail of civil rights of a racial group, exceptionally. Toyosaburo Korematsu v. United States, 323 U.S. 214 (1944) available at: http://caselaw.lp.findlaw.com/ scripts/getcase.pl? court=us\&vol=323\&invol=214 (accessed on: December 29, 2010).

51 Tribe, Laurence H., op. cit., p. 21.

52 Ibidem, p. 29.

53 Idem. 
When Tribe speaks about historically constructed rights — that underlie and give validity to the written Constitution - one notices the same logic of the common law unwritten Constitution that underlies and validates the written Constitution, as interpreted by the Supreme Court of Canada.

The existence of an invisible Constitution, conversely, does not mean a thing in itself apart from its foundation, and it can only be known through the grounds of its content, constructed through the interpretation it is given. It is important to highlight, however, that the content of the invisible Constitution is not indeterminate to the extent that one can find in it anything and everything that one might wish; rather, its content is delimited and must include the broad and general maxims that all in society intuitively accept. ${ }^{54}$

This statement by Tribe is proper to a common law Constitution, which is formed not only by written documents but also by general principles of law, material constitutional rights that were defined during the construction of a particular society.

Another important point is the distinction between axioms and theorems. Although the former are the foundational propositions whose truth is to be assumed or taken for granted, the latter are propositions that can be derived from axioms using rules of logic. In a sense, the visible text of the Constitution contains the explicit axioms of American constitutional law and theory, and those general rules or principles that can be inferred from the Constitution's visible text might be said to comprise a set of theorems constituting a significant part of that body of constitutional discourse and doctrine. ${ }^{55}$

It is the same perspective as that of implicit rights, that is, rights that derive logically from the constitutional structure and system, although Tribe does not admit that the invisible Constitution can be a mere logical consequence of the visible Constitution.

Conversely, stating that the invisible Constitution contains or implies rules that cannot be deduced from the visible text does not mean that the invisible Constitution has nothing to do with the visible text. Moreover, the majority of the invisible Constitution's content interpretation modes involve arguments from the visible text but not ones that can be considered only a logical inference. Conversely, in some cases, the principles of the invisible Constitution are the ones to give content and meaning to the visible text. Moreover, it is through the invisible Constitution that one accepts the

\footnotetext{
54 Ibidem, pp. 34-36.

55 Ibidem, p. 37.
} 
visible Constitution. Thus, the visible text of the Constitution does not contain everything that is axiomatic or fundamental in constitutional theory. ${ }^{56}$ Notice that this statement is consistent with the concept of the common law Constitution developed in Canada, when the Supreme Court of that country made clear the existence of a prior unwritten Constitution that provides grounds to the written Constitution. The written Constitution would be an attempt to express the unwritten Constitution in a visible text.

If the US written Constitution is recognized as the supreme and fundamental law of that nation, then, according to Tribe, there must be something outside the visible text to ensure this status, a combination of how it was originally enacted, how, in what way and by whom it has been accepted over time, and how it is used as reference, serving as a starting point and source of guidance and also as a moral force for the claims made based on the idea of a supreme natural law that it reflects or approaches, or with a basis in another theory of political morality. ${ }^{57}$ Indeed, the invisible Constitution makes the visible Constitution accepted as the fundamental and supreme law of the land.

According to Ackerman, ${ }^{58}$ the US Constitution, as it is understood today, was built in three historical moments: at the time it was ratified, after the Civil War and during the New Deal. ${ }^{59}$

The Constitution, in the tradition of common law and judge-made-law, does not need popular approval to have its interpretation changed because, according to Tribe, it responds and adapts to real world events. ${ }^{60}$

Starting from the premise that the visible text of the US Constitution is formally amended in a forward movement that never backspaces to erase a word that once was in its text, i.e., a unidirectional construction timeline rule exists, one can verify that the amendments have not erased the original clauses but only added others, which demonstrates the endurance quality of every word of that text. This measure serves as an antidote to collective amnesia about national missteps. ${ }^{61}$

\footnotetext{
56 Ibidem, p. 38 .

57 Ibidem, p. 7.

58 Ackerman, Bruce, op. cit., pp. 115 et seq.

59 Tribe, Laurence H., op. cit., p. 52.

60 Ibidem, p. 53.

61 Ibidem, pp. 59-63. Unlike the 1988 Federal Constitution, the amendments repealed or modified the original text.
} 
Conversely, the constitutional history is not airtight. Reactions to real and constitutional events, small or large, also work to reorient constitutional readers, revealing new problems or new opportunities. ${ }^{62}$

The invisible Constitution can result from the judicial interpretation process. There might be a considerable difference between starting from a text and claiming constitutional rights in the absence of a visible Constitution. In the former case, one would at most be faced with an extensive interpretation, whereas the latter case would be a judicial ex nihilo interpretation of constitutional rules without any guarantee. ${ }^{63}$ What occurs is that if there is a social acceptance of the decision made by the Court in the unwritten constitutional law protection or of that present in the invisible Constitution, the constitutionality of the law can have a solid foundation in the politicalconstitutional identity, although there is no written Constitution. ${ }^{64}$

Thus, one would not be starting from scratch to build a new law but from the principles that represent the political morality of a community and that can be present in both a common law Constitution as in an invisible Constitution, from which it is possible to infer abstract principles that substantiated judgments over time.

Although Tribe tries to justify the existence of the invisible Constitution in cases of incompatibility of the original text with the new constitutional amendment, the new document is actually an implied repeal of incompatible previous text. The difficulty of seeing things this way occurs because in the US Constitution, the amendment does not erase the original text. Nevertheless, interpreting the Constitution according to its Amendments does not create an invisible Constitution as the author would have us believe, at least not by this argument.

To Tribe, the principles of constitutional interpretation are located outside the text; even in the Constitutions that refer to certain interpretative rules, it is not possible to establish in its text all of the rules of its own interpretation. ${ }^{65}$

\section{Ibidem, p. 71.}

63 Rosenfeld, Michel, Just Interpretations, Los Angeles, University of California Press, 1998, p. 39.

64 It is possible, in this sense, to make an analogy to what Juha Raitio calls "substantive legal certainty", which encompasses the acceptability of a decision and not only its predictability. See Raitio, Juha, The Principle of Legal Certainty in EC Law, Dordrecht, Kluwer Academic Publishers, 2003, p. 373.

65 Tribe, Laurence H., op. cit., p. 78. 
Tribe's conception about the invisible Constitution cannot be considered natural law, and, obviously, it is not a positivist conception. Instead, it is a vision that involves much more the historicity and contextuality of the Constitution; i.e., being more than the visible text, it should seek its invisibility in American society's paradigmatic historical events, which is the very idea of a common-law unwritten Constitution.

When one speaks about the invisible Constitution, one is referencing what is not visible from the text reading. It is also possible to speak of an invisible Constitution in countries in which there is no written Constitution but in which it is possible to extract from the material Constitution formed by the judicial rulings and laws, which are the supreme norms that are part of its material Constitution.

In this dimension, in the issues related to unwritten constitutional principles concerning the existence of an invisible Constitution, there is a strong influence of history in the consolidation of the rights that are unwritten or invisible to the constitutional text. According to Tribe, it is possible in the US to state the existence of certain constitutional principles that are not written in the text or that are part of the invisible Constitution, namely i) government of laws, not men; ${ }^{66}$ ii) government of the people, by the people and for the people; ${ }^{67}$ iii) suspending habeas corpus $\left.;{ }^{68} i v\right)$ federalism, and v) the right of the people to keep and bear arms.

Some criticisms made against unwritten constitutional rules and principles are of the sense that, unlike written norms, unwritten norms often have a type of fluidity and imprecision that would make them unsuitable for the constitutional law order. They tend to be less precise, less identifiable and much more open to "creative interpretation" by judges and to gradual change, avoiding an application of written rules. Written rules have some clarity, objectivity and stability that derive from being expressed in a formal text. Therefore, even when people disagree on many issues, at least there can be consensus on the written text, with which everyone should agree. With this argument, Waluchow argues that even when written Constitutions are not conceptually necessary, they are highly desirable to establish democratic constitutional states. ${ }^{69}$

\footnotetext{
66 Ibidem, pp. 82-84.

67 Ibidem, pp. 85-91

68 Ibidem, pp. 94 and 95

69 Waluchow, Wil J., A Common Law Theory of Judicial Review: The Living Tree, New York, Cambridge University Press, 2007, p. 49.
} 
The defense of a written Constitution as a norm equipped with certainty and stability is, thus, reasonable. In practice, however, this approach is not taken. Even in countries in which written Constitutions have been adopted, they are made of fundamental principles and rights that, by their nature, have an abstract and open character; therefore, they do allow creative and constructive action by their constitutional Courts, as will be demonstrated in the next section.

\section{CONSTITUTIONAL APPROACHES}

Hence, it is certain that the political morality values ${ }^{70}$ present in a society at any given time are what will give content to constitutional norms. Furthermore, Constitutions such as the Brazilian and American ones have open clauses, i.e., they expressly provide the reception of unwritten constitutional rules outside the Constitution, as long as they are in accordance with the rights and principles contained therein. In other words, these norms, present in both the Brazilian and the American Constitution, point expressly to the existence of other sources of law outside the visible text of the Constitution. ${ }^{71}$

It is in the part of the unlisted rights in the visible Constitution that the invisible Constitution might contribute. In Brazil, it is possible to identify the existence of an invisible Constitution, particularly with respect to the implicit principles, the general principles of law and human and fundamental rights, because of what the Article $5, \S 2$ says of the constitutional charter. This subject will be detailed in the next section.

The provision was inspired by the ninth Amendment of the US Constitution, which states, "The enumeration in the Constitution, of certain rights, shall not be construed to deny or disparage others retained by the people". ${ }^{72}$ This statement is proper in a written Constitution present in a common

70 In this sense, see Dworkin, Ronald, Taking Rights Seriously, Cambridge, Harvard University Press, 1978, pp. 197-203. Dworkin's theory of judicial decision does not represent a choice between his own political beliefs and those he considers the community's political beliefs. Instead, his theory identifies a particular conception of community morality as a decisive factor for legal issues (p. 197). This conception holds that community morality is political morality that laws and community institutions presuppose (p. 201).

71 Tribe, Laurence H., op. cit., p. 146.

72 Constitution of the United States (1787), available at: http://www.embaixada-ame ricana.org. br/index.php? action $=$ materia $\&$ id $=643 \&$ submenu $=106 \&$ itemmenu $=110$ (accessed on: September 10, 2016). 
law tradition country that, together with the explicit and implicit rights of the constitutional text, coexists with the presence of rights and constitutional principles inferred from judicial decisions and constitutional practices throughout history.

The Brazilian Constitution establishes the possibility of principles and implicit rights outside its catalog in its Article 5, $\S 2$, which states that the Constitution welcomes other rights not therein provided as long as they can be derived from its principles, and from international treaties ratified by Brazil. Therefore, in addition to the explicit rights found in international treaties ratified by Brazil, the Brazilian Constitution welcomes other rights deriving from the regime and the principles that it adopts. Consequently, it is possible to defend both the existence of unwritten constitutional principles and of an invisible Constitution in the Brazilian context.

From the mentioned constitutional provision, it is possible to extract the authors' clear intention of allowing the Constitution to adapt itself to changes and new social realities that bring new moral values and customs, thus constantly transforming itself. Only because of this flexibility is it possible to think of a perennial Constitution in time but that at the same time accepts the dynamics of life and develops along with it, welcoming new rights and new social conquests.

In ADI 939, when the Brazilian Supreme Court held that the principle of anteriority in taxes (i.e., freedom from paying taxes in the same year they were imposed) was a fundamental right outside the constitutional catalog, Minister Marco Aurelio de Mello expressed the view that Article $5, \S 2$ of the Constitution admitted the existence of implicit fundamental rights and other rights not expressed in the list of Article 5. ${ }^{73}$

In the same vein, Gilmar Mendes, on the judgment of Federal Intervention $2915-5,{ }^{74}$ argued that the principle of proportionality, although not expressed in the Constitution, could be derived from the substantive due process of law principle. ${ }^{75}$ The same understanding was also defended by Minister Marco Aurélio de Mello during the trial of RE 428,354. ${ }^{76}$

73 Brazilian Supreme Federal Court-STF, ADI 939, Rel. Minister Sydney Sanches, DJU 03/18/1994, available at: http://www.stf.gov.br/ (accessed on: September 10, 2016).

74 Brazilian Supreme Federal Court-STF, IF 2915-5, Rel. Justice Gilmar Mendes, DJU 28.11.2003, available at: http://www.stf.gov.br/ (accessed on: September 10, 2016).

75 Pepper Oliveira, José Roberto, The Principles of Reasonableness and Proportionality in the Brazilian Administrative Law, London, Malheiros, 2006.

76 Brazilian Supreme Federal Court-STF, RE 428.354, Rel. Min. Marco Aurélio de Mello, DJU 18.04.2005, available at: http://www.stf.gov.br/(accessed on: September 10, 2016). 
Minister Gilmar Mendes also argued that the principle of legal certainty is a subprinciple of the State of Law. ${ }^{77}$ Hence, one can safely state that the Brazilian constitutional jurisdiction accepts the presence of implicit or unwritten principles in the Constitution.

Some authors, particularly in the area of administrative law, accept the presence of constitutional principles not expressed in the Constitution, ${ }^{78}$ not examining in detail whether they are implicit, derived from another constitutional norm or, if they are effectively outside the text, existing autonomously.

In this respect, Celso Antônio Bandeira de Mello reasoned as follows about the principle of the supremacy of the public interest over private interest:

The principle of the supremacy of the public interest over private interest is a general principle of law inherent in any society. It is the very condition of their existence. Thus, it is not rooted in any particular provision of the Constitution, although many provisions allude to or result in concrete manifestations of it, for example, the principles of the social function of property, of the consumer's or the environment's protection (art. 170, III, V and VI), and many others. ${ }^{79}$

The author states that this principle is a general principle of law and that, although it is not written in a constitutional provision, countless other provisions allude to or result in concrete manifestations of it. Thus, it is an unwritten principle that can be present in an unwritten or invisible Constitution because the author uses the inductive interpretation method frequently used in common law systems to extract from concrete written rules, an abstract principle. That is, the author applied the inductive method

77 Brazilian Supreme Federal Court-STF, MS 22357, Rel. Justice Gilmar Mendes, DJU 5.11.2004, available at: http://www.stf.gov.br/ (accessed on: September 10, 2016).

78 Gabardo connects the principle of the supremacy of the public interest to Republicans goals, which are a manifestation of that principle, whereas the principle provides them grounds. "The principle of the supremacy of the public interest, in the terms established in the Brazilian constitutional system... is a clear manifestation of the allocation in the State of the primary duty of promoting [the] Republican objectives of Article 3 of the 1988 Constitution". Gabardo, Emerson, Interesse público e subsidiariedade: o Estado e a sociedade civil além do bem e do mal, Belo Horizonte, Forum, 2009, p. 292.

79 Bandeira de Mello, Celso Antônio, Curso de direito administrativo, 27a. ed., São Paulo, Malheiros, 2010, p. 96. 
to achieve the general principle starting from the constitutional provision of Article 170, III, V and VI of the Brazilian Constitution, thus assuming that these articles are written expressions of the unwritten principle of the supremacy of the public interest.

Similarly, the author says that the principle of supremacy of the public interest conditions the existence of society itself because he believes that there are historically constructed supreme values that are prior to the written Constitution.

It could be argued, inclusively, that the general principles of $1 \mathrm{aw}^{80}$ are part of an unwritten Constitution because they are often not expressed in any positive text but can be extracted from them with an inductive interpretation.

Although the Federal Constitution of 1988 did not expressly provide in Article 5, $\S 2$ an openness to fundamental rights and unwritten principles —including both implicit and derived ones - one could still state the existence of implicit rights because they derive from the hermeneutic activity. ${ }^{81}$

80 "To hold that the general principles are norms, the arguments are two and both are valid. First of all, if one calls norms those from which the general principles are extracted, through a successive generalization procedure, there is no reason why they should not be considered norms as well; if one abstracts from animal species, he shall always get animals, not flowers or stars. Second, the function to which they are extracted and employed is the same for all norms, that is, the function of regulating a case. And for what purpose are they extracted in cases of normative gaps? To rule a non-regulated behavior; but then they serve the same purpose as the express rules. And why should they not be norms?" (Bobbio, Norberto, Teoria do ordenamento jurídico, Brasilia; Universidade de Brasilia, 1999, p. 158). Josef Esser also defends the presence of general principles of law prior to the written law with the same legal force as the written law: "In the background of positive norms, there always is a latent principle of law that, once discovered, has in itself enough momentum to automatically gain a level equal to the law itself" (Esser, Josef, Principio y norma en la elaboración jurisprudencial del derecho privado, Barcelona, Bosch, 1961, p. 498).

81 Thus, Paulo Schier explains that "from the reading of art. 5, $\S 2$, of the Republican Constitution, it is certain that we now have fundamental rights in the catalog (both expressed and implicit) and fundamental rights outside the catalog (also express and implicit). Among these, that is, within those outside the catalog, it would still be possible to subdivide two categories of fundamental rights: those resulting from the legal regime adopted by the Constitution, but embodied in the formal Constitution itself, and those resulting from international human rights treaties and thus not belonging, at least not directly, to the formal constitutional document (although accepted by it)". See Schier, Paulo, "Novos desafios da filtragem constitucional no momento de neoconstitucionalismo", A\&C Revista de Direito Administrativo e Constitucional, no. 20, 2005, p. 152. 
In Brazil, the materiality able to identify fundamental rights and constitutional principles outside the catalog essentially occurs when one relates them to the dignity of the human person. In other words, the rights that will be considered fundamental are those that, although not expressed in the list of Article 5 of the Constitution, have any relationship with the dignity of the human person.

Ingo Wolfgang Sarlet sees the possibility of deduced autonomous fundamental rights without any direct reference to another fundamental right, as long as its fundamental materiality is present, which, for the author, would be linked to human dignity. ${ }^{82}$

However, the understanding of another part of the doctrine is considered more appropriate. That part holds that the fundamentality of a right results from the connection of a particular norm with one of any of the fundamental constitutional principles, not only with the dignity of the human person. ${ }^{83}$

Similarly, Brazilian doctrine and the Supreme Court accept the presence of materially constitutional norms outside the Constitution; these norms are referred to as the "constitutional block".

Thus, in the trial of RE $248.869,{ }^{84}$ the Supreme Court recognized the fundamental right to a name and affiliation. In the same direction, Minister Celso de Mello, in the trial of RE 466.343, ${ }^{85}$ argued that the Pact of San Jose of Costa Rica integrates the constitutional block.

Adopting the presence of a constitutional block (bloc de constitutionalité) in Brazilian law means having as a constitutional parameter, according to Gomes Canotilho, the global constitutional order. That is, "the reason for the constitutional legitimacy of normative acts must be defined not only according to the written rules and principles of constitutional laws but also considering unwritten principles that integrate the global constitutional order" ${ }^{86}$ extending the parameter to the principles claimed by "the spirit" or by the "values" that inform the global constitutional order, including

82 Sarlet, Ingo Wolfgang, Dignidade da pessoa humana e direitos fundamentais na Constituição Federal de 1988, 4a. ed., Porto Alegre, Lawyer Bookstore, 2006, p. 102.

83 Schier, Paulo, op. cit., p. 152.

84 Brazilian Supreme Federal Court-STF, RE 248.869, Rel. Min. Maurício Correa, DJU 12.03.2004, available at: http://www.stf.gov.br/ (accessed on: September 10, 2016).

85 Brazilian Supreme Federal Court-STF, RE 466.343, Rel. Min Cezar Peluso, DJU 05.06.2009, available at: http://www.stf.gov.br/ (accessed on: September 10, 2016).

86 Gomes Canotilho, José Joaquim, op. cit., pp. 853 and 854. 
both international treaties of human rights and the materially constitutional norms present in infra-constitutional legislation.

However, according to the scholium of Celso Lafer, the norms of international human rights treaties integrate the block of constitutionality, which is understood as "a set of rules containing provisions, principles and values that, in the case, in alignment with the 1988 Constitution, are materially constitutional, though outside the text of the documental Constitution" ${ }^{87}$

The constitutionality block can thus be understood as "the sum of what is added to the written Constitution, due to the values and principles enshrined therein", ${ }^{88}$ and although not expressed in the written text of the Constitution, is endowed with normative strength and serves as a material parameter to control the constitutionality of laws.

In the next section, the study of the Constitution as a living document that develops and changes according to the historical and social context of the community, without changing its formal text, will be presented.

\section{LIVING CONSTITUTION}

Another theme present in the context of common law constitutionalism and that is likely to have a match in Brazilian constitutionalism is the idea of a living Constitution. A living Constitution is one that develops, changes over time and adapts itself to new circumstances without needing to be formally amended. ${ }^{89}$

If the Constitution were a living document that changes according to the new political, economic, social, historical and cultural circumstances, there would be a contradiction with the very intention of a stable and protectedfrom-human-manipulation Constitution. How does one reconcile a written and static Constitution with a live and dynamic Constitution in the same system?

When the US Supreme Court or the Brazilian Supreme Court interprets a law, there is a concern with the words written in the law. However, this concern should not occur when interpreting the Constitution because cons-

87 Lafer, Celso, A internacionalização dos direitos humanos: constituição, racismo e relações internacionais, São Paulo, Manole, 2005, pp. 15-18.

88 Idem.

89 Strauss, David A., The Living Constitution, New York, Oxford University Press, 2010 , p. 1. 
titutional interpretative work requires much more than the text. In this case, the interpreter must turn to the understandings about certain rights that have developed within and outside the courts.

Notice that the structure of the Brazilian Constitution, for example, particularly in establishing fundamental principles and rights, because of its open and abstract character, allows its content to have certain flexibility ${ }^{90}$ and fluidity. That is, it allows changes in interpretation of the text because it is inherent in the very nature of the Constitution, which is understood as a living document.

However, to avoid having a living Constitution reduced to what judges want it to be, changing its meaning without any commitment to precedents or its constitutional history, one will also seek in the study of a living Constitution to understand how it is possible to keep the protection of a stable Constitution and at the same time allow it to meet social expectations.

When doctrine and the Brazilian Courts close their eyes to the reality that the Constitution is more than its text and that its structure, grounded in fundamental rights and principles of an open and abstract character and accepting the densification of its contents in accordance with cultural, historical values of a society, they pretend that the Constitution allows the security desired by its citizens, consenting, on the contrary, that the judiciary might be free to decide based on political, pragmatic and contingency pressures, undermining the very notion of the Constitution.

However, the Constitution should be viewed as a living instrument that grows and adapts itself to contemporary circumstances, trends and beliefs, an instrument whose authority is based on the justice, commitment, consensus and sovereignty of the current people, who legitimate it. ${ }^{91}$

It is in this sense that it is argued that the Constitution is a living document, and the unwritten principles or the ones present in an invisible Constitution, in fact, can be considered principles that were developed by the Courts, in the American case particularly by its Supreme Court, through a common law process. ${ }^{92}$

90 “...most constitutions, because of their need for flexibility and for adaptability in the face of evolving circumstances, contain general, open-ended provisions that seem particularly prone to interpretive abuse". Rosenfeld, Michel, op. cit., p. 3.

91 Waluchow, Wil J., op. cit.

92 David Strauss questions where American basic principles of freedom of expression come from, such as, for instance, the one that says it is important to protect the right to criticize the government or the one that says that not all discourses (such as the obscene or the defamatory) should be constitutionally protected. He replies: “...the text and the 
In fact, these principles have been developed and worked on to cover policies and political morality issues, particularly bearing in mind what might make sense and still have good results. Similarly, there was an explicit consideration of policy, justice, viability and political morality issues within certain limits, which shows, according to Strauss, the common law method characteristics. ${ }^{93}$

Despite admitting that the US Constitution is a living Constitution, which includes precedents and traditions developed over time, the importance of the Constitution's stable and enduring text is also certain. Thus, the dilemma that arises is, how can we reconcile a dynamic common law Constitution with an unchanging but important and central constitutional text? ${ }^{94}$

The text will serve as a starting point shared by the community; that is, some issues need not be discussed all of the time. The importance of a constitutional text is much more the stabilization of social relations or the symbolism of what it represents, because even when one does not agree with some issue in the Constitution, there is a consensus that it is better to have that provision than not to have it.

Notice that in the United States of America, a country with a common law tradition, the Constitution functions as an instrument to ensure the stability of social relations, not in isolation but together with the common law method of binding to precedents.

In countries that have adopted the legal system of the common law tradition, stability was not built on the idea that a written text would cover all issues. Rather, it was developed in a coherent movement to construct the law through judicial precedents and by valuing equity in judicial decisions.

Conversely, the desired stability in countries of the Roman-Germanic tradition was built upon the idea of the completeness of the system; in other words, the system would provide certainty and predictability because it allegedly provided a legal solution to any issue that might appear in social relations.

By the occasion of the adoption of democratic Constitutions with a catalog of fundamental rights, in the post-war period, the intention was to

original understandings of the First Amendment are essentially irrelevant to the American system of freedom of expression as it exists today. The central principles of that system have been worked out by the courts, principally the Supreme Court, through a common law process: the living Constitution in action”. Strauss, David A., op. cit., p. 56.

93
94
9 Ibidem, p. 62. 
interpret these new Constitutions as though they had the feature of a code, transferring this very thought of completeness of the Law and of guaranteed security to the written text.

Hence, most European countries in the post-war adopted the formal model of a Constitution's supremacy, along with the stiffness model, intending thereby to ensure the immutability and security of its text, whether to protect it from the ordinary legislator or from the judge.

The structure of the new Constitutions, with a detailed list of fundamental principles and rights, did not exhaust the content of its rules in the constitutional text due to the rules that set out the principles and fundamental rights, which have extra-textual sources of meaning and allow a constant and non-exhaustive construction of their meanings. Thus, the norm shall only exist concretely.

The doctrine thus developed the concept of constitutional mutation for the informal changes of the Constitution's content, without any need to change its text via a qualified and formal amendment process. ${ }^{95}$

In the US one speaks of a living Constitution and unwritten principles to signify what the constitutional practice and interpretation is or what effectively is the real Constitution outside its text. However, in European countries and in Brazil, all with tradition in civil law, the doctrine uses the term "constitutional mutation" to explain the shifts in the interpretation of the Constitution without changing its text.

The Brazilian and European doctrine appears to be afraid of the idea of constitutional change, particularly because the informal character of amending the Constitution via interpretation makes it difficult to control its constitutionality and because of the possibility of allowing the judiciary to obtain significant power through its interpretative role. ${ }^{96}$

95 Jellinek distinguishes Mutation from Reform using the element of intentionality, that is, constitutional reform derives from voluntary and intentional actions, whereas constitutional mutation would be the transformation of the Constitution without the intention of its agents. In addition, constitutional mutation has as a characteristic the change of Constitution interpretation without any changes in its express text. Jellinek, Georg, Reforma y mutación de la Constitución, trans. of Christian Foster, Madrid, Constitucionales Studio Center, 1991, p. 7 apud Sánchez Urrutia, Ana Victoria, "Mutación constitucional y fuerza normativa de la Constitución. Una aproximación al origen del concepto", Revista Española de Derecho Constitutional, vol. 20, no. 58, 2000, p. 110.

96 Thus, Eneida Desiree Salgado analyzes the subject using extensive Brazilian and European writings. She shows great concern with the difficulty of controlling constitutional mutation carried by the judiciary. "Thus the understanding of Gilmar Ferreira 


\section{FINAL REMARKS}

The concern with the role of the Courts in interpreting the Constitution and with its limits is also present in all of the countries with tradition in civil law and in common law, the latter being more used to this role of judgemade law of the judges. ${ }^{97}$ However, the idea of limiting the interpretative role of the Judiciary will not be found in the constitutional text but rather in the consistency of the common law method of using judicial precedents, which is also true in the Brazilian context.

In countries with a Roman-Germanic tradition, the idea of rigidity and supremacy is very tied to the text of the Constitution, to the link with positivism, to the false assumptions that the texts and the codes would be complete and that the language used would limit the role of the judiciary to being one of the interpreters of this language.

Limiting the interpreter through language is not possible because language itself allows different understandings depending upon who reads its content, according to the background of the interpreter. This variability occurs with law and literature and with works of art and literature texts; neither the work nor the text can support the meaning achieved by each interpreter.

What is occurring is that the content of constitutional rules that establish fundamental principles or rights due to their open and abstract character has flexibility and fluidity. In other words, their open and abstract nature

Mendes, Inocêncio Mártires Coelho and Paulo Gustavo Gonet Branco: the change of interpretation, however, has to find support in the content of the words used by the constituent and must not violate the structural principles of the Supreme Law; otherwise, there will only be an unconstitutional interpretation. Although it is logical to argue in that sense and to argue that this statement arises from the constitutional system, there is no juridical remedy to correct an informal change of the Constitution that did not respect these limits when the agent is the Supreme Court. The Court's action in this sense, however, leads to discredit of the role of the Constitution, caused by who has the duty to protect it. By modifying the Constitution, the judiciary exceeds the powers entrusted to it by the Constitution and is appropriating the sovereignty and the constituent power". Salgado, Eneida Desiree, Princípios constitucionais estruturantes do direito eleitoral, Thesis (Doctor of Law), Curitiba, UFPR, 2010, p. 99, available at: http://dspace.c3sl.ufpr.br/dspace/ bitstream/1884/22321/1/Tese_Eneida_Desiree_Salgado.pdf.

97 David A. Strauss says: "...most of the attacks on the idea of a living Constitution portray the courts as the problem: to say we have a living Constitution is to license the courts to do what they want". Strauss, David A., op. cit., p. 118. 
allows changes in the interpretation of the text because it is inherent in the nature of a living Constitution. We cannot claim that the constitutional text alone limits the performance of the judiciary.

Consequently, when it is assumed that the Constitution is a living document, it also must be assumed that the document develops and adapts to circumstances and current beliefs. Its legitimacy, then, will be in the justice, consensus, commitment and sovereignty of the current people and not only in the original constituent power. ${ }^{98}$

In this new context, the Constitutional judges will have the difficult role of making a contemporary interpretation of ancient rights. This task should be done by being loyal to constitutional and at the same time imaginative values when answering the questions that appear in pluralistic and complex contemporary societies ${ }^{99}$ in a consistent and limited way, limited not in the text but in the set of principles that reflect the morality of their community.

\section{BIBLIOGRAPHIC}

ACKerman, Bruce, We the People: Foundations, Massachusetts, The Belknap Press of Harvard University Press, 1991.

Allan, T. R. S., "In Defence of the Common Law Constitution: Unwritten Rights as Fundamental Law", LSE Legal Studies Working Paper 5, January 22, 2009, available at: http://ssrn.com/abstract $=1331375$ or http://dx.doi.org/10.2139/ssrn.1331375 (acessed on: August 17, 2018).

98 Waluchow, Wil J., op. cit., p. 55. Similarly Philippe Blachèr wrote: “As Dominique Rousseau emphasized, «the founding principles are not things definitely solidified in the historical moment of their enunciation». For his interpretation of constitutional principles, the judge establishes a bridge between two instances of people: the people of the living and the principles previously established by their ancestors. Similar to the image of the US Supreme Court, the constitutional Council is presented as a «constitutional mediator» between the «trans-temporal people» and the «current people» (free translation). Blachèr, Philippe, Contrôle de constitutionnalité et volonté générale, Paris, Presses Universitaires de France, 2001, p. 190.

99 Markovits, Inga, "Constitution Making After National Catastrophes: Germany in 1949 and 1990", William and Mary Law Review, no. 4, 2008, p. 1307, available at: http:// wmlawreview.org/issues/49. "Judges thus should be alert to the political and social culture of their day. This is particularly true in post-totalitarian democracies that have to learn a new moral vocabulary and in which unforeseen difficulties and the lack of political experience may require imaginative responses". 
Bandeira de Mello, Celso Antônio, Curso de direito administrativo, 27a. ed., São Paulo, Malheiros, 2010.

Bickel, Alexander M., The Least Dangerous Branch: The Supreme Court at the Bar of Politics, 2a. ed., New Haven, Yale University Press, 1986.

BlACHER, Philippe, Contrôle de Constitutionnalité et volonté générale: La loi votée... n'exprime la volonté générale que dans le respect de la Constitution, Paris, Presses Universitaires de France, 2001.

BoBBIO, Norberto, Teoria do ordenamento jurídico, Brasilia, Universidade de Brasilia, 1999.

DwORKIN, Ronald, Levando os direitos a sério, São Paulo, Martins Fontes, 2002.

DwORKIN, Ronald, Taking Rights Seriously, Cambridge, Harvard University Press, 1978.

ESSER, Josef, Principio y norma en la elaboración jurisprudencial del derecho privado, Barcelona, Bosch, 1961.

GABARDO, Emerson, Interesse público e subsidiariedade: o Estado e a sociedade civil além do bem e do mal, Belo Horizonte, Forum, 2009.

GolDSwOrTHY, Jeffrey, "Unwritten Constitutional Principles", Expounding the Constitution. Essays in Constitutional Theory, New York, Cambridge University Press, 2008.

Gomes CANOTILHO, José Joaquim, Direito constitucional e teoria da Constituição, 3a. ed., Coimbra, Almedina, 2000.

LAFER, Celso, A internacionalização dos direitos humanos: constituição, racismo e relações internacionais, São Paulo, Manole, 2005.

LECLAIR, Jean, "Canada's Unfathomable Unwritten Constitutional Principles", Queen's Law Journal, no. 27, 2001-2002.

MARKOVITS, Inga, "Constitution Making After National Catastrophes: Germany in 1949 and 1990", William and Mary Law Review, no. 4, 2008, available at: http://wmlawreview.org/issues/49 (accessed on: April 10, 2015).

MunRo, William Benett, The Makers of the Unwritten Constitution: The Fred Morgan Kirby Lectures, s.1., Delivered at Lafayette College, 1929.

PePper OliveIRA, José Roberto, The Principles of Reasonableness and Proportionality in the Brazilian Administrative Law, London, Malheiros, 2006. 
QueIroz BARBozA, Estefânia Maria de, Constitutional Jurisdiction: Between Constitutionalism and Democracy, Belo Horizonte, Forum, 2007.

RAITIO, Juha, The Principle of Legal Certainty in EC Law, Dordrecht, Kluwer Academic Publishers, 2003.

Rosenfeld, Michel, Just Interpretations, Los Angeles, University of California Press, 1998.

SAlgado, Eneida Desiree, Princípios constitucionais estruturantes do direito eleitoral, Thesis (Doctor of Law), Curitiba, UFPR, 2010, available at: http://dspace.c3sl.ufpr.br/dspace/bitstream/1884/22321/1/Tese Eneida_Desiree_Salgado.pdf(accessed on: April 10, 2015).

SÁNCHEZ URRUTIA, Ana Victoria, "Mutation constitutional y fuerza normativa de la Constitución. Una aproximación al origine del concepto", Revista Española de Derecho Constitutional, vol. 20, no. 58, 2000.

SARLET, Ingo Wolfgang, Dignidade da pessoa humana e direitos fundamentais na Constituição federal de 1988, 4a. ed., Porto Alegre, Lawyer Bookstore, 2006.

SCHIER, Paulo, "Novos desafios da filtragem constitucional no momento de neoconstitucionalismo", A\&C Revista de Direito Administrativo e Constitucional, no. 20, 2005.

Strauss, David A., The Living Constitution, New York, Oxford University Press, 2010.

TRIBE, Laurence H., The Invisible Constitution, New York, Oxford University Press, 2008.

WALTERS, Mark D., "The Common Law Constitution in Canada: Return of Lex no Scripta as Fundamental Law", The University of Toronto Law Journal, vol. 51, no. 2, spring, 2001.

WALTERS, Mark D., "Written Constitutions and Unwritten Constitutionalism”, en Huscroft, Grant (ed.), Expounding the Constitution: Essays in Constitutional Theory, New York, Cambridge University Press, 2008.

Waluchow, Wil J., A Common Law Theory of Judicial Review: The Living Tree, New York, Cambridge University Press, 2007.

Fecha de recepción: 4 de agosto de 2017.

Fecha de aceptación: 27 de abril de 2018. 